\title{
Religion and Secularism
}

\author{
Pravesh Kumar Srivastava \\ Professor, Dept. of Ancient Indian History, Culture \& Archaeology, \\ Banaras Hindu University (BHU), Varanasi, UP, India
}

The relevance of religion is of paramount importance in the life of human being from the dawn of civilization to develop humanity. In India, the word 'dharma' has been used in the sense of religion. But in fact religion is not exact word for dharma, religion contains only theology meaning but the dharma consists of many things including religion where as theology, morality and duties also. From the beginning of civilization, religion has played a powerful role in shaping the social behaviors. Here is the great work of interpretation or hermeneutics. We conduct a kind of exegesis because studies of religion are not final but incomplete. As said above, method is normative; and one of the rules to consider is the knowledge, the importance, the progression and the content of the necessary phases. Thus, there is a time for formulating hypotheses, which can be formulated theory or an opinion or a belief or a presumption, a question. There will a time for collecting data or gathering materials, or selecting some writings. In summary, these steps are heuristic process, hermeneutic work and composition. The term 'dharma' stands for all those ideals and purposes, influences and institutions that shape the character of man both as an individual and as a member of society. It is the law of right living, the observance of which secures the double object of happiness on earth and salvation. Religions help an individual in his efforts to realize an ideal, the ideal of perfection and provide an inner urge to move towards it. If society to be lifted out of the morass into which it has fallen today, individual men and women have to recreate them. They find out the meaning and purpose of life. It is the business of religion to restore belief in the purpose of life and give zest and meaning to it. It will be sufficient here to state that religion always effects to society and we can use the virtues of religion in modern era for maintaining the harmony of society. The Hindu religion is unique in the sense that it is the only surviving major religion today that has retained a continuous link with its hazy origins in antiquity. Hinduism has no founder, no code of beliefs; it never had any religious organization that wielded temporal power over its followers. Its distinguishing characteristics are its diversity and multiplicity. The term Sanatana dharma, which is also used to refer to this religion reflects its character - Sanatana means continuing. The religions of the Mesopotamians, ancient Greeks and Romans were similar to Hinduism. But they were replaced by Christianity and Islam. The Hindu doctrine of having an ishta-devata (chosen deity) invites every Hindu to select his de ity from the wide pantheon of various gods and goddesses conceived since time immemorial. While this liberal doctrine was originally applied to the numerous deities mentioned in the Hindu scriptures, there is no logical stopping point, and hence the same tolerant attitude is taken towards other religions who have defined frontiers. "Hinduism thus holds that there are many ways, many paths which lead towards salvation or spiritual liberation. Historically it has convincingly demonstrated this belief.

In addition to Sikhs, Jains and Buddhists, who have emerged as reform movement from Hinduism, we have had communities of Jews, Syrian Christians, and Zoroastrians who settled in India and lived there unmolested. Muslims lived peacefully in India for three hundred years before Islam came as a military force in the eleventh century A.D. Hinduism, unlike Buddhism, Christianity and Islam, is not a missionary religion, and the rejection of proselytism on principle is regarded by many Hindus as an important part of tolerance". Thus "tolerance is a strong point in support of the secular state ".

\section{From ancient India, we have so many sculpture and architectural evidences to proof the secular sentiments of ancient Indian people.There are some examples of Temples.}

Rameshwaram (or Rameswaram) is a small island town in Tamil Nadu and is one of the four holiest pilgrimage places (Char Dhams) of the Hindus. The reason for its being so sacred is the belief that Lord Rama along with his wife Sita first landed on its shore after defeating the demon Ravana (who was also a Brahmin). To seek atonement for killing a Brahmin, Rama wanted to worship Shiva for which he sent Hanuman to Kailash to 
bring an idol of the God. In the mean time, Sita made a small lingam is called Ramalingam and another one brought by Hanuman is called V ishwalingam. As per the instructions of Lord Rama, Vishwalingam is worshiped before the Ramalingam, even today.

\section{RAMESHWARAM-TEMPLE}

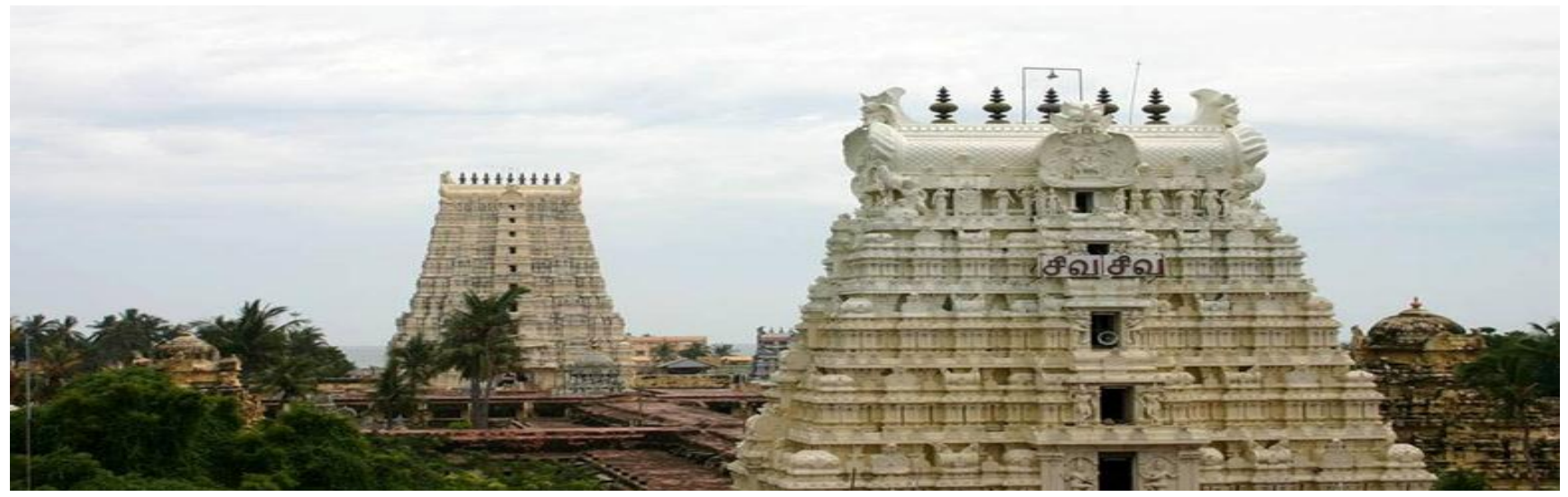

Lingaraja temple is one of the oldest and largest temples of the 'Temple City of India' - Orissa. Drenched in the architectural style typical of Kalinga, the temple doesn't only attract religious devotees but also the historians. The idol of Lingaraj usually represents Lord Shiva, but over here it symbolizes Shiva and Vishnu. The combined form of both the Gods is referred to as Harihara. A large lake called Bindu Sagar touches the temple from one side and is said to have healing powers. Non-Hindus are not allowed to enter the premises, thus they can see the magnificent structure from a platform outside the temple. Shivratri is the main festival of the temple.

\section{LINGRAJA-TEMPLE}

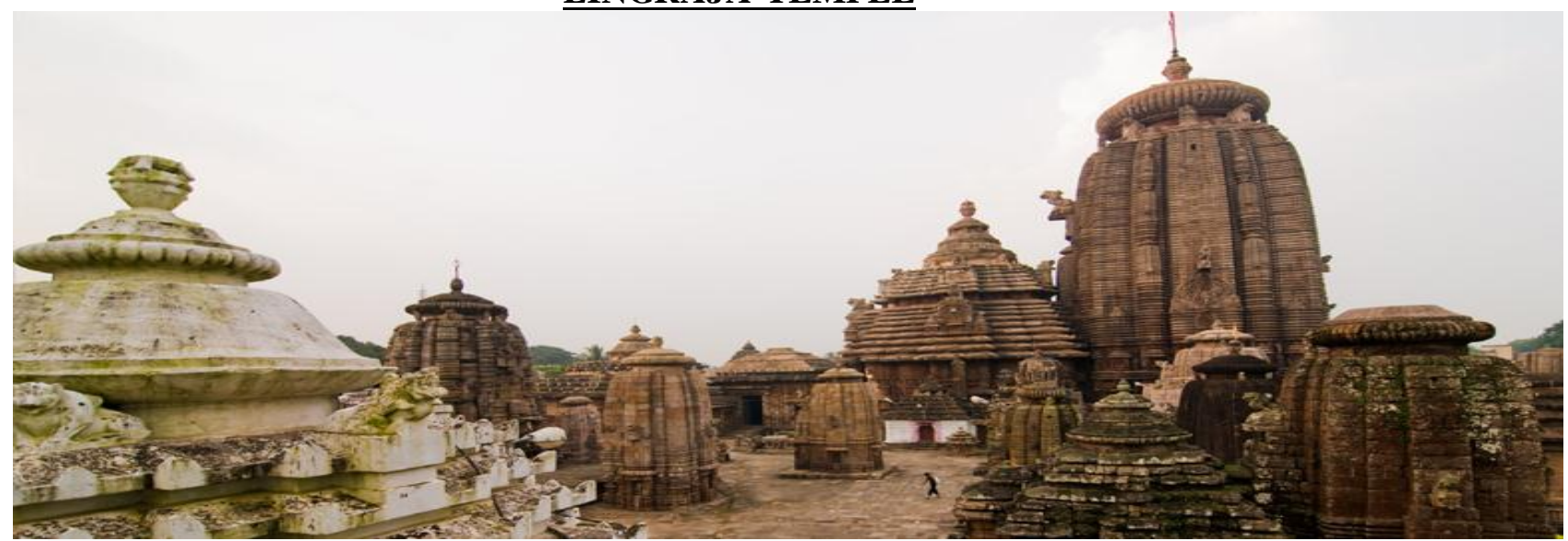

Ellora caves, a world heritage site, are in the Indian state of Maharashtra. The 35 caves were carved into the vertical face of the Charanandri hills between the 5th and 10th centuries. The 12 Buddhist caves, 17 Hindu caves and 5 Jain caves, built in proximity, suggest religious co-existence and secular sentiments for diversity prevalent during pre-Islamic period of Indian history 


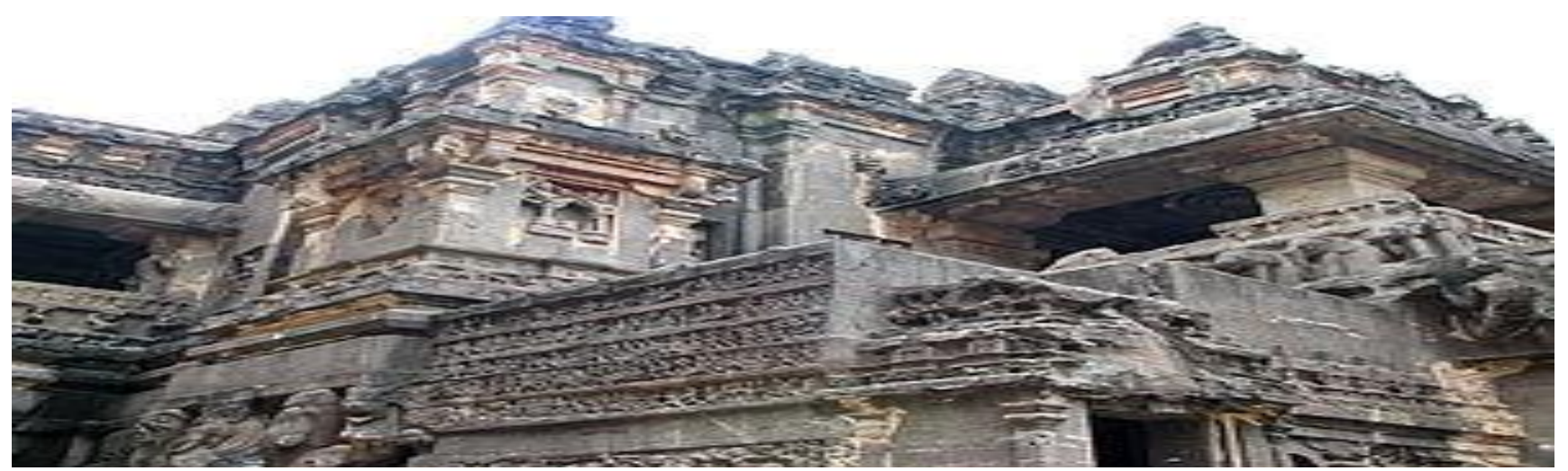

ELLORA-CAVE-TEMPLE

Built during the reign of Mughal emperor Shah Jahan in 1656, Shri Digambar Jain Lal Mandir is the oldest Jain temple in Delhi. Made in the honor of the 23rd Tirthankara, Parashvanath, the temple is made in red sandstone.(Standing right across the Red

\section{JAIN-TEMPLE}

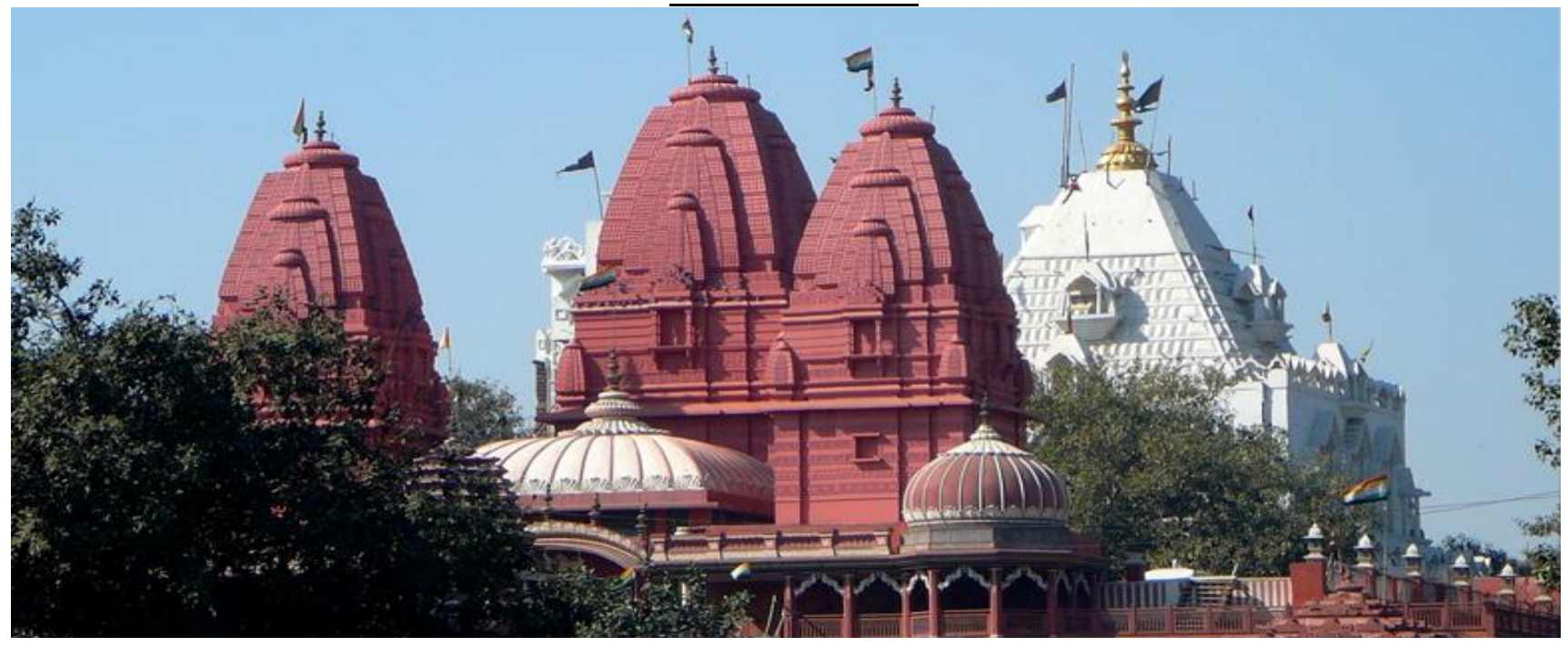

Khajuraho is a town in the state of Madhya Pradesh, which houses several temples built between 10th to 12th centuries. Spread across an area of $20 \mathrm{sq} \mathrm{km}$, the monuments of the town are recognized as UNESCO World Heritage Site. The temples are built of sandstone and dedicated to the deities of Hindus and Jains. The temples are world famous for the erotic cravings, which can be seen along other cravings depicting the activities of routine life. It is believed that there were over 75 temples in the area but right now about 20 exist. The temples have been divided into three zones - eastern, western and southern. The Western zone consists of the most famous temples; the largest temple of Khajuraho, Kandariya Mahadeva Temple, falls under this zone. 
KANDARIA-TEMPLE

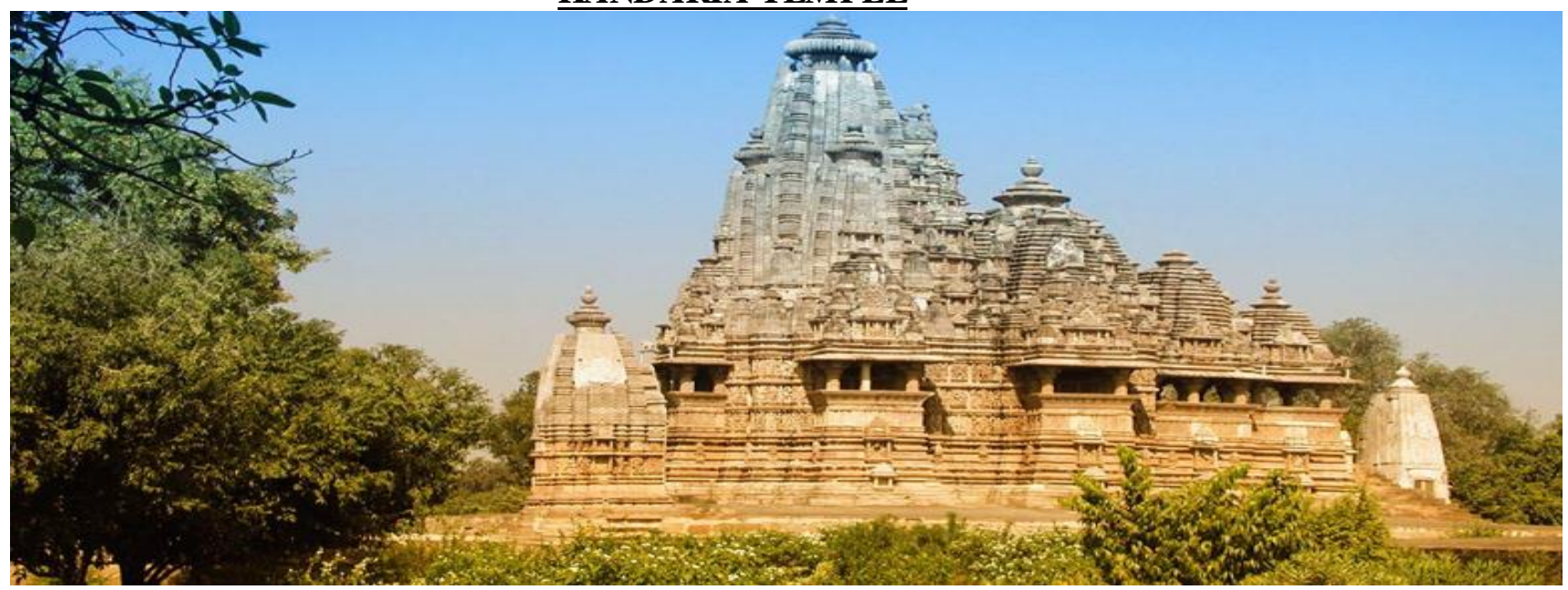

The Khajuraho group of temples belong to Vaishnavism school of Hinduism, Saivism school of Hinduis m and Jainism - nearly a third each. Archaeological studies suggest all three types of temples were under construction at about the same time in late 10th century, and in use simultaneously. Will Durant states that this aspect of Khajuraho temples illustrates the tolerance and respect for different religious viewpoints in the Hindu and Jain traditions. ${ }^{[51]}$ In each group of Khajuraho temples, there were major temples surrounded by smaller temples - a grid style that is observed to varying degrees in Hindu temples in Angkor Wat, Parambaran and South India.The largest surviving Saiva temple is Khandarya Mahadeva, while the largest surviving Vaishnava group includes Chaturbhuja and Ramachandra.Kandariya Mahadeva Temple plan is $109 \mathrm{ft}$ in length by $60 \mathrm{ft}$, and rises $116 \mathrm{ft}$ above ground and $88 \mathrm{ft}$ above its own floor. The central padas are surrounded by three rows of sculptured figures, with over 870 statues, most being half life size (2.5 to 3 feet). The spire is a self repeating fractal structure.

\begin{tabular}{|c|c|c|c|c|c|}
\hline $\begin{array}{l}\text { Sr. } \\
\text { No. }\end{array}$ & Temple name & Religion & Deity & $\begin{array}{l}\text { Completed by }(\mathrm{CE}- \\
\text { AD })\end{array}$ & Image \\
\hline 1 & Chausath Yogini & Hinduism & $\begin{array}{l}\text { Devi, } \\
64 \text { Yoginis }\end{array}$ & 885 & \\
\hline 2 & Varaha & Hinduism & Vishnu & 950 & \\
\hline
\end{tabular}




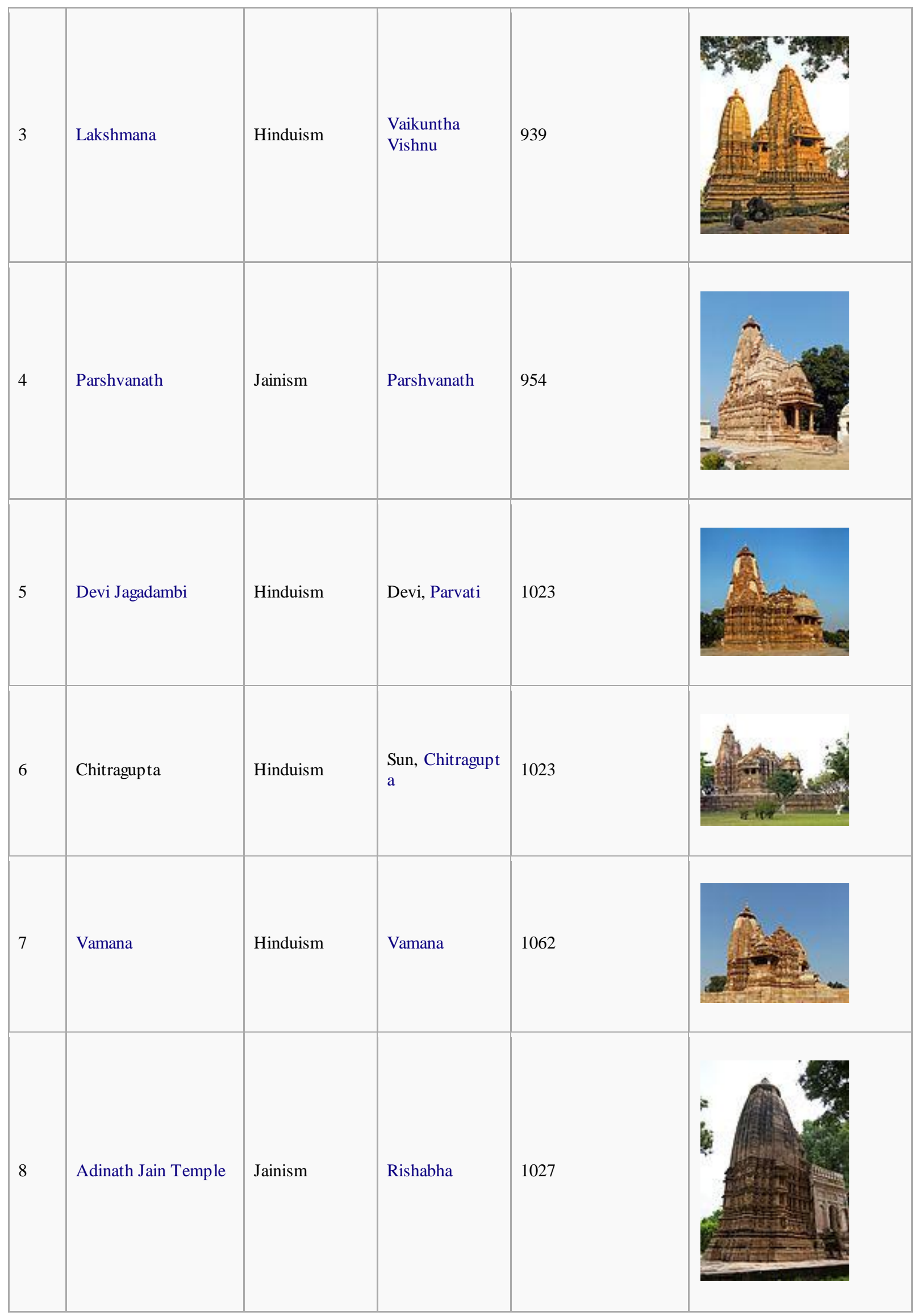




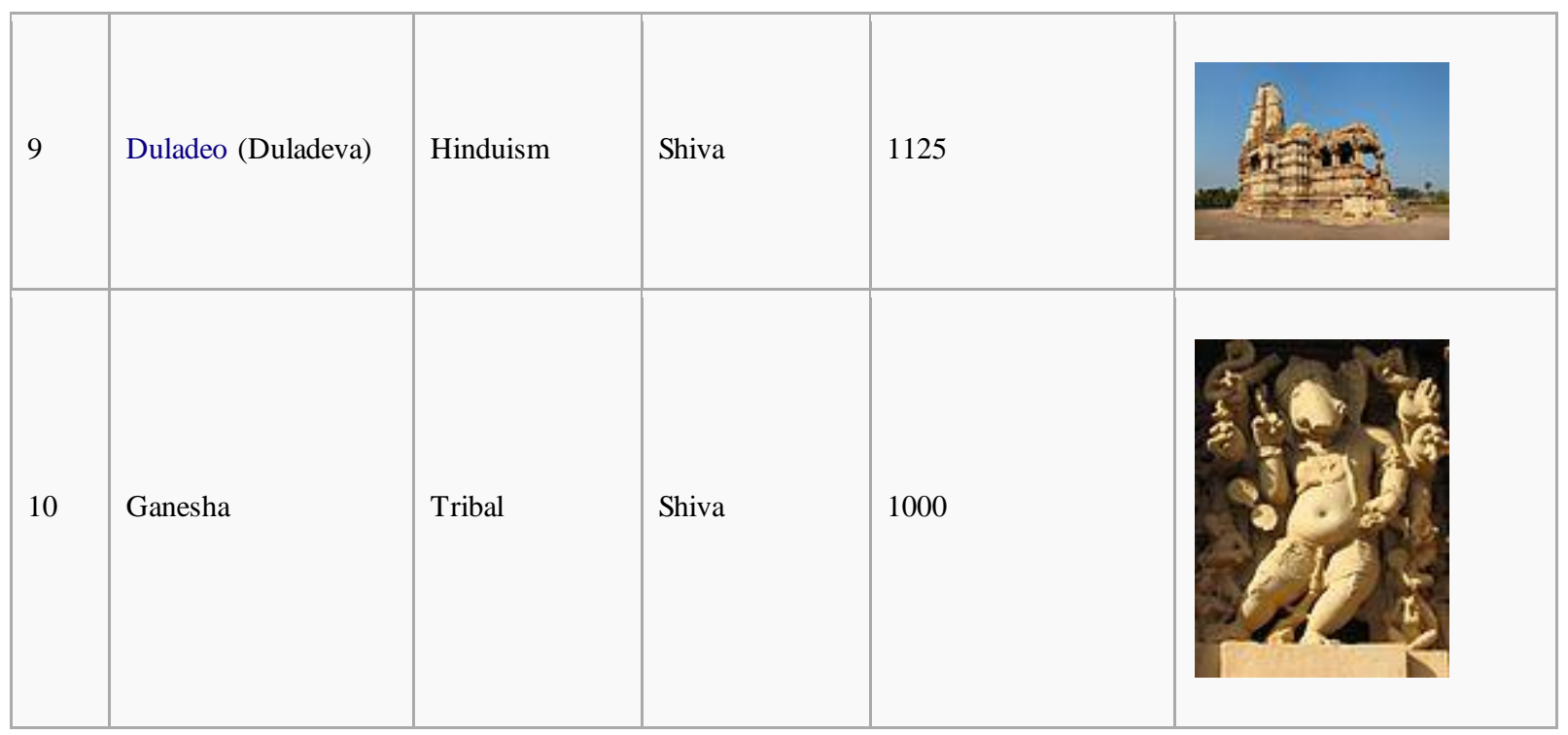

A Hindu temple in Jaipur, India merging the traditional tiered tower of Hinduism, the pyramid stupa of Buddhism and the dome of Islam. The marble sides are carved with figures of Hindu deities, as well as Christian Saints and Jesus Christ.

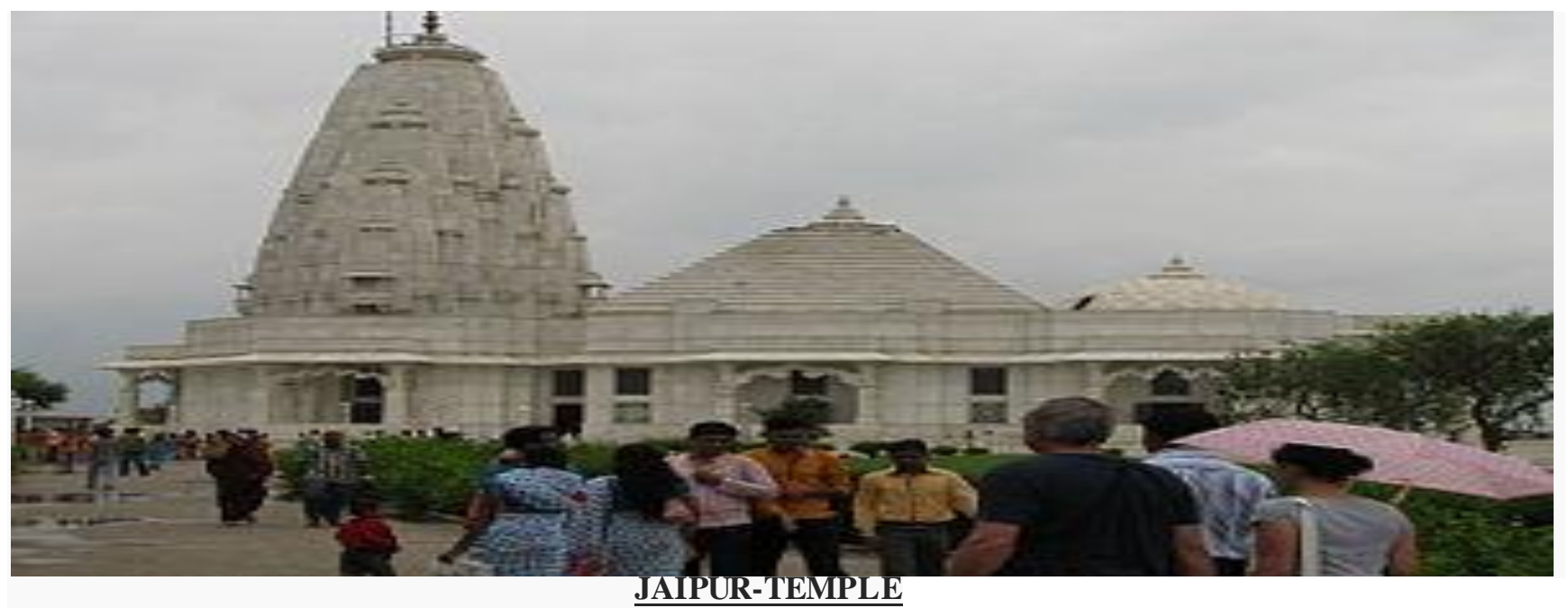

India always followed the great tradition of 'Sarva dharma sambhava' i.e. all religions are harmonious with each other and lead to God and thus one can follow the path he or she chooses. The Vedic seer had proclaimed "Truth is one; people call it by various names" (Ekam Satya, Viprah Bahuda Vadanti). Tolerance and harmony is a weave through Indian philosophy, culture and society since ages. Hindu scholars displayed towards other religions were subtle and symbolic and most likely was done to present a superior argument in defense of their own faith. Traditionally, Hindus showed their intolerance by withdrawing and avoiding contact with those whom they held in contempt, instead of using violence and aggression to strike fear in their hearts. Hinduis $m$ is perhaps the only religion in the world which showed remarkable tolerance towards other religions in difficult times and under testing conditions. Even Buddhism, which spread in India mostly through negative campaigns against Hinduism, cannot claim that credit. Criticizing other religions and showing them in poor light to attract converts to its own fold was never an approved practice in Hinduism. The following points amply prove that Hinduism is incomparable in its tolerance and attitude towards other faiths. There are some interesting facts about Indian religion followers. 
1. In its thousands of years of history, no Indian ruler had ever launched a religious war against other nations. . The kings of ancient India never enforced their religious beliefs upon people. The strictly followed the policy of non-interference. They built temples and places of worship, practiced their own faith, patronized scholars and spiritual gurus of their choice, but never oppressed those who practiced other faiths.

2. From the earliest times Indian society has been a heterogeneous society in which people belonging to different linguistic, ethnic, social and economic backgrounds lived in harmony, practicing their respective faiths without pressure or interference from others. For most people, faith was a personal choice or family tradition in which others had no role. Even now, people do not mind who worships whom as long as the choices are conventional. However, if a person converts to either Christianity or Islam you may expect disbelief and disapproval from friends and close members of the family mainly because of the social repercussions of such actions.

3. Interactions and exchange of ideas among scholars of various faiths in the form of debates and discussions was a regular feature of ancient India. Even the Buddha participated in them. In places like Takshasila and Nalanda, which were famous centres of traditional education, people participated in religious debates to improve their knowledge and understanding.

4. The Bhagavadgita clearly upholds the practice of tolerance. It firmly declares that the paths to God are many and all reach Him only in the end. It also encourages people to practice their own dharma instead of following that of others, even if it is superior. The scripture clearly distinguishes divine qualities from demonic ones and the need to follow virtue and righteousness in one's conduct.

5. Hindus never persecuted religious teachers and spiritual masters who questioned the validity of the Vedas or held unconventional beliefs within Hinduism itself.

6. Spiritual masters like Ramakrishna and Vivekananda showed remarkable tolerance in the ir own teachings and conduct. They upheld all religions, emphasized the importance of communal harmony and drew the attention of people to the similarities between the teachings of Hinduism and other religions.

7. Upon gaining independence, even though the country was partitioned on religious grounds and a vast majority of Indians were Hindus, India opted for secular democracy and provided equal opportunities to people of all religions. Despite many problems and provocations, by and large, Hindus displayed great restraint in the ir attitude and conduct towards other faiths. A large share of the credit for communal harmony in India goes to Hindus, despite the fact that India had to deal with numerous instances of religious terrorism, missionary zeal and communal violence, which often resulted in widespread destruction of property and loss of life.

8. Despite centuries of oppression, destruction of their temples and religious places and violent religious persecutions, and acts of terrorism a majority of Hindus remain largely friendly and conciliatory towards other faiths without resentment or rancour in their hearts.

9. Hinduis $m$ does not active ly pursue religious conversions. Underlying this is the belief that a person becomes a Hindu because of past karmas (work). If a person is not ready, there is no point in trying to convert him and interfere with his karmic destiny.

10. Unlike many nations in the world, where people uniformly practice a monolithic religion, from the earliest times India was a pluralistic society in which people belonging to different ethnic and racial backgrounds practiced numerous faiths without resorting to communal or religious wars. The very fact that Hinduism itse lf is an amalgamation of numerous traditions proves the point that tolerance was a way of life in ancient India. This would not have happened, had Hinduism been an intolerant religion like Islam or Christianity.

The religious tolerance of present day Hinduism is partly influenced by conventional wisdom and partly by the values of democracy and modern education. Not all Hindus practice religious tolerance equally. On the one end you have the enlightened and knowledgeable ones who want to display extreme tolerance in the face of extreme aggression. On the other end you have those who want to retaliate and answer violence with violence. In between the two groups fall the majority of Hindus with varying degrees of tolerance and intolerance. This group remains largely peaceful and tolerant, but when passions are incited, one can feel their frustration and anger in public and on the social networks. The intolerance of many present day Hindus, in fact, is an acquired trait, learned in response to the intolerance they get to see in other communities. A section of Hindus have reached the end of their threshold of tolerance, holding that enough is enough and it is time Hindus begin to assert themselves and stand united. By and large, Hindus are amiable and peace loving, who dis play remarkable 
pride in their religious identity and its historical distinction. They have suffered enough, sacrificed enough and endured enough to understand the agony of religious discord.

Amidst the tumult of discordant voices, they also recognize the importance of living in peace. Many Indians are politically conscious. They display a remarkable knowledge of the world and the events that happen in the other parts of the world. They are well aware of the divisive nature of religion and its adverse effects upon the interests of a nation. Therefore, they understand well that for the order and regularity of a pluralistic society, religious tolerance is a compelling necessity. No country can make progress, if its people remain divided. A majority of Hindus recognize this fact and try to get on with their lives ignoring the stray incidents of communal violence that keep happening in various parts of the world. Social, political and economic compulsions also make tolerance a compelling case for the members of a pluralistic society to follow.

Hinduism is a tolerant and flexible religion. It is free from the oppression of dogma and the pressures of an organized religion. It is very tolerant, lenient and forgiving towards its own followers and gives everyone great freedom to practice their faith according to their convictions and convenience. Today, anyone can join Hinduism and practice it without any official or baptismal ceremony. In a very broad sense, it is a democratic tradition which verges on the side of anarchy. Therefore, the concept of tolerance is nicely integrated in the way of life it upholds. (by Jayaram V-Hinduism and religious tolerance)

Contemporary society is modern and extremely complex. Due to the industrial revolution and modernization, the whole world has become a global village. Advanced information technology and new economic policy (Globalization, Privatization and Liberalization) have changes the structure of the entire society. In this fast and ever changing world, economic and material factors are more emphasized. Owing to this, social, religious, political and cultural institutions have undergone a change drastic. Religion still plays an essential part in the modern society and controls different aspects of people's lives, e.g. ideologies, belief system, marriage, political participations inter-groups relations etc. In India the Hindus, Muslims, Christians, Buddhists, Sikhs, Janis and Parsee are the major religious groups. These religions differ in their basic ideologies and values. A certain level of similarity is noticed in these religious groups, e.g. all religions stress the higher virtues of life for instance, truth, benevolence, non-violence, faith etc. However, dissimilarity is equally observed due to the existence of numerous castes, sub castes different life system, rituals and practices. As a result of this heterogeneity, national, integration seems to be a difficult objective to achieve. If every citizen of India respects the principle of secularism, the inherent difference between the religions can be overcome and India can rise as a strong, undivided developed nation. National integration is hindered by the vested interests of the politicians who use and glorify religion to stimulate the sentiments of the people for their own or party interests. Other factors can be stated such as religious fundamentalism, communalism and factionalis $\mathrm{m}$. At the same time, the problem of religious terrorism is developing as an issue of great concern the world over including India. A humanitarian approach alone can bring about social and national progress.

\section{Bibliography}

[1] Bauddhayan Dharma Sutra- Shastri Chinnat Swami, Chowkhambha Sanskrit Series, Banaras.1934.

[2] East and West in Religion, Dr.S.Radhakrishnan, London- George Allen and Unwin Ltd.1923.

[3] Indian Philosophy - Vol. I, Dr.S.Radhakrishnan, Published in Library of Philosophy London: George Allen and UnwinLtd. 1st Ed -1923.

[4] Kautaliyamarthasastram of Acharya Vishnuguta Vol-2 Part one with four commentaries Edited by Visvanath Sastri Qatara, Published by: Sampurnanand Sanskrit University, Varanasi.

[5] Manu Smiriti- Shastri Hari Govind, Chowkhambha Sanskrit Series, Banaras. 1956.

[6] Nalanda Devanagri Pali Series, The Jataka (Part I), Khuddakanikaya Vol. III Part I,General Editor,Bhikku J Kashyap1959,Pali Publication Board Bihar Government.

[7] Prachin Bhartiya Abhilekh Sangrah, Part I- Goyal SriRam, Rajsthan Hindi Granth Akadami, Jaipur,1982.

[8] Radha Krishnan, Translator, Nand Kishore Gobhil Vidyalankar,Bhartiya Darshan,Rajpal and Sons -1969.

[9] Rig-Veda Samhita (Mandalas 1-10),Edited by K.L. Joshi Pd. 2000 AD,Chowkhambha Orientalia Varanasi.

[10] Religion and Society, Dr.S.Radhakrishnan, London-George Allen and Unwin Ltd.1947 Second Ed 1948.

[11] Religion and Culture, Dr.S.Radhakrishnan, Delhi, Pocket Books 1968

[12] Sankaracharya (Bhasya),Chandyog Upanisad, Gita Press Gorakhpur, Vikram Samvat-1994.

[13] Sankaracharya (Bhasya),Tattiriya Upanisad, Gita Press Gorakhpur, Vikram Samvat-2016.

[14] Sankaracharya (Bhasya),Vrihadaranyak Upanisad, Gita Press Gorakhpur, Vikram Samvat-2014.

[15] Satpatha Brahmana- Weber A., Leipzig, 1924. 
[16] Shukla - Yajurveda-Samhita,Edited byPandit Jagdishlal Sastri,(c) Motilal Banarsidas,Jawahanagar,Delhi-7,Chowk, Varanasi.

[17] Tattriya Aryanak- Omte Hari Narai, Poona.1890.

[18] The Anguttara Nikaya, Navakanipata, Dasakanipata and Ekadasakanipata General Editor,Bhikku J Kashyap-1960, Pali Publication Board Bihar Government.

[19] The Reign of Religion UN Contemporary Philosophy, Dr.S.Radhakrishnan, London: Macmillan and co. 1920.

[20] The Samyutta Nikaya, 2-3 Nidanavagga and khandhavagga,General Ed itor Bhikku J Kashyap-1959, Pali Publication Board Bihar Government.

[21] The Theragatha-Atthakatha Paramatthadipani Vol. I,General Editor,Dr. Nathmal Tatia,Editor,Dr. Angraj Chaudhary,Nava Nalanda Mahavihara Nalanda Bihar- CE 1976.

[22] The Sacred of the East- translated by various oriental scholars And edited by F. Max Muller Volume XLIV,First published by the Clarendan Press 1900,Reprinted by Motilal Banarsidas 1963,1966,1972,1977,Indological Publishers and book sellers,Delhi

[23] Upanishad-Vakya-Maha-Kosa Vol-I, Shastri Gajanan Shambhu Sadhale First Published-1940, Reprint-1991, Rupa Books Pvt. Ltd. Jaipur.

[24] (W. Crooke, 'Hinduism, - Encyclopedia of Religion and Ethics,' ed. James Hastings, 1925, Vol 6) 